Int. J. Dev. Biol. 58: 189-198 (2014)

doi: $10.1387 / \mathrm{ijdb} .140054 \mathrm{ae}$

\title{
T cell behavior at the maternal-fetal interface
}

\author{
PATRICE NANCY ${ }^{1}$ and ADRIAN ERLEBACHER ${ }^{*, 1,2}$ \\ ${ }^{1}$ Department of Pathology and ${ }^{2}$ NYU Cancer Institute, NYU School of Medicine, New York, USA
}

\begin{abstract}
Understanding the function of $T$ cells at the maternal-fetal interface remains one of the most difficult problems in reproductive immunology. A great deal of work over the last two decades has led to the view that the T cells that populate the decidua have important roles in both normal and pathological pregnancies, but the exact nature of these roles has remained unclear. Indeed, the old assumption that decidual T cells are uniformly threatening to fetal survival because the placenta is fundamentally an 'allograft' has given way to the idea that different $T$ cell subsets contribute in different ways to pregnancy success or failure. Accordingly, some T cells are thought to protect the placenta from immune rejection and facilitate embryo implantation, while others are thought to contribute to pregnancy pathologies such as preeclampsia and spontaneous abortion. Here, we review the current state of information on the behavior of decidual $T$ cells with a focus on both mouse and human studies, and with an emphasis on the many unresolved areas within this overall emerging framework.
\end{abstract}

KEY WORDS: Fetomaternal tolerance, pregnancy, decidua, placenta, antigen presentation

\section{Introduction}

Many different kinds of maternal leukocytes populate the maternal-fetal interface (i.e. the decidua), each with diverse functions in implantation, placental development, parturition and infectious disease control (for review, see Bulmer et al., 2010, Erlebacher, 2013a, Trundley and Moffett, 2004). For example, natural killer cells (NK cells) are well known as critical regulators of spiral artery remodeling in both mice and humans. Here we will discuss the role of decidual $\alpha \beta$ T cells (henceforth referred to as simply T cells), whose functions remain particularly poorly understood. The difficulty on working on these cells in part comes from the existence of multiple $T$ cell subsets possessing diverse sets of functions. In addition, each $T$ cell possesses a distinct antigen specificity as determined by its uniquely expressed T cell receptor (TCR) generated during T cell development in the thymus as the result of TCR $\alpha$ and TCR $\beta$ gene rearrangements. Nonetheless, subset differentiation and antigen specificity will ultimately be central to understanding the function and significance of decidual T cells. Due to the complexity of these issues, we begin with a broad introduction into T cell biology, along with a brief historical perspective on the role of $T$ cell subsets in pregnancy. We then move on to the specifics of $T$ cell biology at the maternal-fetal interface, with an emphasis on the many unresolved issues concerning these cells. Several of the pathways we cover are diagrammed in Fig. 1. An introduction to natural killer T (NKT) cells, CD4- CD8- T cells, and $\gamma \delta$ T cells, which are relatively rare in the pregnant uterus, can be found elsewhere (Tilburgs et al., 2010a); other reviews of decidual $\alpha \beta$ T cells, with additional perspectives, can also be found elsewhere (Ernerudh et al., 2011, Saito et al., 2010, Teles et al., 2013b, Tilburgs and Strominger, 2013).

\section{T cell activation and subsets - a primer}

Following their development in the thymus, Tcells are considered to be naïve until they first encounter cognate peptide antigen. This encounter takes place in the secondary lymphoid organs - i.e. the spleen for blood-borne antigens and the regional lymph nodes for blood-borne antigens and antigens that drain via lymphatic vessels from peripheral tissues - and entails interactions with dendritic cells (DCs) that present the cognate antigen on their cell surface in association with major histocompatibility complex (MHC) molecules. For CD4 T cells, TCR signaling is stimulated upon engagement of peptide antigen:MHC class II complexes; for CD8 T cells, TCR

\footnotetext{
Abbreviations used in this paper: APC, antigen presenting cell; CTL, cytotoxic T lymphocyte; DSC, decidual stromal cell; DC, dendritic cell; MHC major histocompatibility complex; HLA, human leukocyte antigen; $\mathrm{iT}_{\mathrm{Reg}}$ cell, induced $\mathrm{T}_{\mathrm{Reg}}$ cell; IFN $\gamma$, interferon- $\gamma$; NK cell, natural killer cell; NKT cell, natural killer T cell; nTreg cell, natural $\mathrm{T}_{\mathrm{Reg}}$ cell; $\mathrm{T}_{\mathrm{Reg}}$ cell, regulatory CD4 $\mathrm{T}$ cell; $\mathrm{T}_{\mathrm{RM}}$ cell, resident memory T cell; TCR, T cell receptor; TNF $\alpha$, tumor necrosis factor- $\alpha$; VUE, villitis of unknown etiology.
}

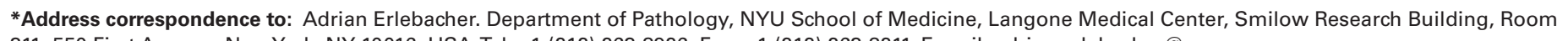
311, 550 First Avenue, New York, NY 10016, USA. Tel: +1-(212) 263-8926. Fax: +1-(212) 263-8211. E-mail: adrian.erlebacher@nyumc.org

Final, author-corrected PDF published online: 8 July 2014.

ISSN: Online 1696-3547, Print 0214-6282

(C) 2014 UBC Press

Printed in Spain 
signaling is stimulated upon engagement of peptide antigen:MHC class I complexes. If the DC also supplies sufficient costimulation, which includes critical signals generated from the surface molecules CD80 and CD86, the responding T cell proliferates (i.e. undergoes clonal expansion) and then differentiates into one of several T cells subsets as specified by the set of cytokines encountered during antigen exposure. As discussed below, these subsets are $T_{H} 1$, $\mathrm{T}_{\mathrm{H}} 2, \mathrm{~T}_{\mathrm{H}} 17$ effector CD4 T cells, regulatory CD4 $\mathrm{T}\left(\mathrm{T}_{\mathrm{Reg}}\right)$ cells, and cytotoxic T lymphocytes (CTLs), which are effector CD8 T cells. Once activated, an effector $T$ cell exits the spleen or lymph node and then homes via the blood to the peripheral tissues. Although a relatively open area of research, $T$ cell behavior within peripheral tissues is also thought to be actively regulated through pathways that include local antigen presentation and cytokine production by DCs and macrophages, as well as cross-inhibition of the different $\mathrm{T}_{\mathrm{H}}$ cell subsets via their own production of cytokines.

\section{Effector CD4 T cells}

$T_{H} 1, T_{H} 2$, and $T_{H} 17$ cells are the three main effector CD4 $T$ cell subsets currently known (for review, see (Zhu et al., 2010)). They are defined by the set of transcription factors they respectively express in order to maintain their differentiated state, as well as

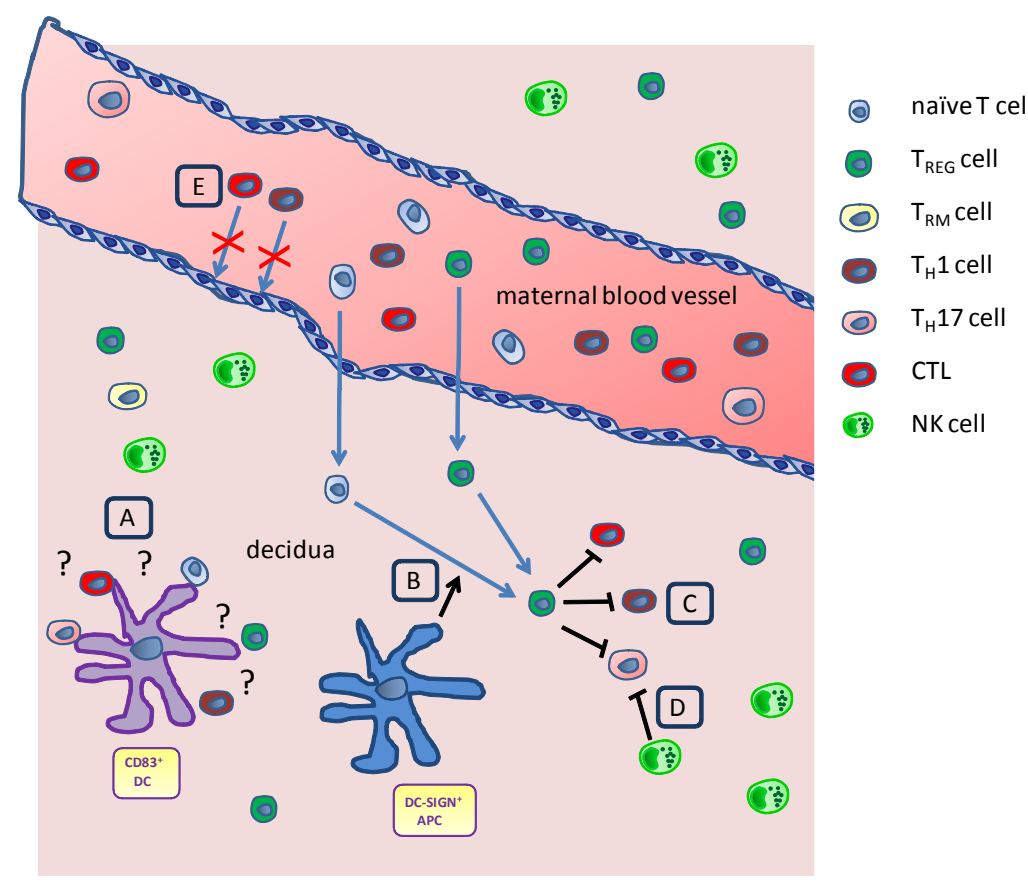

Fig. 1.T cell behavior at the maternal-fetal interface. A schematized representation of the pregnant uterus, illustrating several of the regulatory pathways discussed in this review. (A) CD83+ DCs form clusters with decidual T cells, which presumably reflects ongoing antigen presentation. The significance of this observation is not currently known, nor are the $T$ cell subsets involved (naïve, regulatory, effector, memory). (B) The potential role of decidual CD14+ DC-SIGN+ APCs in converting naive decidual $T$ cells into $T_{\text {Reg }}$ cells. (C,D) The potential role of $N K$ cells and $T_{\text {Reg }}$ cells in repressing decidual CTLS, $T_{H} 1$ and $T_{H} 17$ cells. (E) Impeded $T_{H} 1$ cell and CTL recruitment to the decidua from the blood as a result of $\mathrm{Cxcl9}, \mathrm{Cxcl} 10, \mathrm{Cxcl11}$, and Ccl5 chemokine gene silencing in decidual stromal cells. Naïve T cells and $T_{\text {Reg }}$ cells are shown entering the decidua from maternal blood, however there is currently no direct evidence that this happens to a major extent. The idea that naive T cells enter into the decidua from the blood is particularly unlikely. by the set of cytokines they express that mediate their effector functions. In addition, each subset expresses a characteristic set of chemokine receptors that directs recruitment to sites of inflammation by promoting the extravasation of the cells across the endothelium. Consequently, the set of chemokine ligands expressed by an inflamed tissue will determine to a large extent the effector $T$ cell subsets that can gain access to this tissue.

$\mathrm{T}_{\mathrm{H}} 1$ cells primarily function within peripheral tissues to promote the eradication of virus-infected cells and intracellular pathogens. The cells express the transcription factors T-bet and STAT4, and secrete interferon- $\gamma$ (IFN $\gamma$ ) as their signature cytokine. They also express the chemokine receptors CXCR3, which is the receptor for CXCL9 (MIG), CXCL10 (IP-10), CXCL11 (I-TAC), and CCR5, which is a receptor for CCL5 (RANTES). IFN $\gamma$ produced by $T_{H} 1$ cells promotes macrophage activation as well as stromal and endothelial cell expression of the CXCL9, CXCL10, and CXCL11, which means that activated $T_{H} 1$ cells promote both their own recruitment as well as the recruitment of CTLs, which also express CXCR3 (Nakanishi et al., 2009). $\mathrm{T}_{\mathrm{H}} 1$ cells also produce tumor necrosis factor- $\alpha(T N F \alpha)$, which serves to promote inflammation in a variety of ways. Importantly, $\mathrm{T}_{\mathrm{H}} 1$ cells are the primary CD4 $T$ cells that drive surgical allograft rejection and therefore have long been considered major threats to fetal survival and potential contributors to pregnancy pathologies.

$\mathrm{T}_{\mathrm{H}} 2$ cells primarily function in allergic reactions through their regulation of antibody isotype switching, and in the eradication of helminths. The cells express the transcription factors GATA3 and STAT6, secrete the cytokines IL-4, IL-5 and IL-10, and preferentially express the chemokine receptor CCR4, which is required for migration to sites of allergic inflammation such as the airways. Historically, interest in $\mathrm{T}_{\mathrm{H}} 2$ cells in pregnancy has come from the fact that these cells provided an alternative, less potentially embryotoxic differentiation state for CD4 T cells in comparison to $T_{H} 1$ cells, as well as the ability of $T_{H} 2$ cytokines to repress $T_{H} 1$ cell differentiation and function in trans. Thus, it had been thought that pregnancy would involve a general Th2-skewing of the $\mathrm{T}$ cell response in order to minimize the generation of $\mathrm{T}_{\mathrm{H}} 1$ cells. A great deal of data, however, has rendered this idea overly simplistic (discussed further in (Saito et al., 2010)).

$\mathrm{T}_{\mathrm{H}} 17$ cells augment acute inflammatory responses and mediate host immunity against extracellular bacteria and fungi. The cells express the transcription factors ROR $\gamma$ t, STAT3 and IRF4, and secrete members of the IL-17 family of pro-inflammatory cytokines, most notably IL-17A. IL-17Aacts on epithelial cells to induce neutrophil chemoattractants such as CXCL1 and neutrophil survival factors such as G-CSF. The predominant chemokine receptor of $T_{H} 17$ cells is CCR6, which attracts them to epithelial surfaces expressing their ligand CCL20. As the most recently described $T_{H}$ cell subset, their role in reproduction is only now beginning to be elucidated.

\section{Cytotoxic T lymphocytes}

CTLs are the CD8 T cell counterparts of effector $T_{H} 1$ cells, and like $T_{H} 1$ cells play a major role in virus and intracellular pathogen clearance. They express the same 
set of transcription factors (T-bet and STAT4) and cytokines (IFN $\gamma$ and $T N F \alpha$ ) as $T_{H} 1$ cells, and their recruitment to peripheral tissues is similarly governed by localized expression of CXCR3 and CCR5 ligands. In contrast to $\mathrm{T}_{\mathrm{H}} 1$ cells, however, CTLs have the capacity to directly kill target cells by virtue of their expression of the cytolytic molecules perforin and granzyme. These molecules are released upon TCR-mediated interactions with target cells expressing cognate peptide:MHC class I complexes. As with $\mathrm{T}_{H} 1$ cells, CTLs play a major role in graft rejection and so too have been considered direct threats to fetal survival. This view has been tempered, however, by the realization that invasive trophoblasts, in both mice an humans, express a limited set of classical MHC class I molecules (King et al., 2000, Madeja et al., 2011), which means that there is less opportunity for CTLs to directly attack the placenta as they might a surgical organ transplant. On the other hand, the cytokines IL-12 and IL-18 produced by DCs and macrophages can induce CD8 T cells to produce IFN $\gamma$ in a TCR-independent manner (Freeman et al., 2012). Thus, the mere presence of these cells at the maternalfetal interface has, in principle, the potential to augment decidual inflammation to the detriment of pregnancy success.

\section{Regulatory T cells}

$T_{\text {Reg }}$ cells suppress the activity of other immune cell types and are involved in down regulating immune responses after the elimination of invading organisms, in preventing autoimmunity, and in minimizing pathogenic responses to commensals (for a review, see Campbell and Koch, 2011). The cells are defined by their expression of the FOXP3 transcription factor, and are identified as such using intracellular staining protocols in conjunction with the cells' CD4 ${ }^{+}$CD25 ${ }^{\text {hi }}$ surface phenotype. The cells express a wide variety of different chemokines receptors, and so have a rather promiscuous homing capacity. $\mathrm{T}_{\text {Reg }}$ cells are thought to primarily mediate their immunosuppressive effects though secretion of the cytokines IL-10 and TGF- $\beta$, as well as by acting as a sink for IL-2, which is a T cell mitogen and the ligand for CD25. $T_{\text {Reg }}$ cells are further classified in two groups based upon their origin. Natural $\mathrm{T}_{\text {Reg }}\left(\mathrm{nT}_{\text {Reg }}\right)$ cells are generated in the thymus directly from $\mathrm{T}$ cell precursors and have reactivity towards self antigen. As a result, these cells are primarily thought to be involved in preventing the development of autoimmune reactions. In contrast, induced $\mathrm{T}_{\text {Reg }}$ ( $\mathrm{iT}_{\mathrm{Reg}}$ ) cells are generated in secondary lymphoid organs from naïve CD4 $\mathrm{T}$ cells following their simultaneous exposure to innocuous foreign antigen and TGF- $\beta$. $\mathrm{iT}_{\text {Reg }}$ cells are therefore thought to play a specialized role in mitigating pathogenic responses to commensal flora. Recently, $\mathrm{nT}_{\text {Reg }}$ cells and $\mathrm{iT}_{\text {Reg }}$ cells, including those within the human decidua, have been distinguished by virtue of their differential expression of the Helios transcription factor, but the use of this marker has been challenged (Akimova et al., 2011, Gottschalk et al., 2012, Verhagen and Wraith, 2010).

Interest in the role of $\mathrm{T}_{\text {Reg }}$ cells in pregnancy, which is currently very intense, was initially stimulated by the dual findings that the cells increased in frequency in blood during both human and mouse pregnancy (Aluvihare etal., 2004, Somerset etal., 2004), and were required to prevent pregnancy failure in mice in allogeneic mating combinations (Aluvihare et al., 2004) (of note, the finding of $\mathrm{T}_{\text {Reg }}$ cell expansion during human pregnancy has since become controversial; Ernerudh et al., 2011). More recently, the CNS1 enhancer element of the FOXP3 gene, which is specifically required for $\mathrm{iT}_{\text {Reg }}$ cell generation, was found to exist only in placental mammals, being absent from even monotremes and marsupials (Samstein et al., 2012). This result suggested a highly specific role for $\mathrm{iT}_{\text {Reg }}$ cells in pregnancy, potentially both systemically and at the maternal-fetal interface. We discuss the possible role of $T_{\text {Reg }}$ cells within the decidua further below (for an additional review, see Ernerudh et al., 2011); their potential systemic function during pregnancy has been discussed elsewhere (Erlebacher, 2013b).

\section{Memory and tissue resident memory $\mathrm{T}$ cells}

Virtually all effector T cells generated in response to an immunogenic antigen undergo apoptosis once antigen clearance is complete. However, a few of these antigen-experienced cells survive and differentiate into memory $T$ cells, which are capable of mounting rapid responses after a second contact with antigen. Classically, memory cells have been divided into two subsets based upon their homing patterns (for review, see Mueller et al., 2013). Central memory T cells express CD62L (L-selectin) and the chemokine receptor CCR7 and recirculate throughout the blood and secondary lymphoid organs like naïve T cells. In contrast, effector memory T cells are CD62 - CCR7- and recirculate throughout peripheral tissues patrolling for antigen. More recently, a third class of memory $T$ cells has been described, termed resident memory $T$ cells ( $T_{\mathrm{RM}}$ cells) that, as implied by their name, remain stationary within the tissues where they are thought to provide an immediate, yet antigen-specific, defense against a re-infecting pathogen (Mueller et al., 2013). These cells have recently been identified in the mouse reproductive tract (Schenkel et al., 2013), but their role in pregnancy has not yet been investigated.

\section{T cell composition in the decidua}

A thorough analysis of the Tcell subset composition of the mouse decidua has not been published. Compared to other leukocyte subtypes such as NK cells and monocytes, T cells are quite rare, and comprise only about $3 \%$ of total decidual leukocytes on embryonic day (E) 8.5 (Croy et al., 2012 and Nancy and Erlebacher, unpublished data). The cells are split about 50:50 between CD4 and CD8 T cells (Croy et al., 2012), and approximately 15\% of the CD4 T cells are FOXP3 ${ }^{+} \mathrm{T}_{\text {Reg }}$ cells on E13.5-14.5 (Samstein et al., 2012). The proportion of these $T_{\text {Reg }}$ cells that are $n T_{\text {Reg }}$ versus $\mathrm{iT}_{\text {Reg }}$ cells is unknown. In contrast, a great deal more work has been performed on the human decidua, where $\mathrm{T}$ cells comprise a much greater proportion of total leukocytes (10-20\%; for review see Erlebacher, 2013a). About $\sim 30-45 \%$ of the cells are CD4 T cells and 45-75\% are CD8 T cells (Bulmer et al., 1991, Marlin et al., 2011, Mjosberg et al., 2010, Tilburgs et al., 2009b, Vassiliadou and Bulmer, 1996), with the large majority of both subsets being antigen-experienced (CD45RA- or CD45RO+) (Saito et al., 1994, Slukvin et al., 1996, Tilburgs et al., 2010b). Based upon their chemokine expression profile, putative $\mathrm{T}_{\mathrm{H}} 2$ and $\mathrm{T}_{\mathrm{H}} 17$ cells comprise only $\sim 5 \%$ and $2 \%$ of first trimester decidual CD4 T cells, respectively, while $\mathrm{T}_{H} 1$ (CCR4- CXCR3 $^{+} \mathrm{CCR}^{-}$) cells surprisingly comprise $\sim 5-30 \%$ of the cells (Mjosberg et al., 2010). About 5\% of the CD4 T cells are CD25 ${ }^{\text {hi }} \mathrm{FOXP}^{+} \mathrm{T}_{\text {Reg }}$ cells (Mjosberg et al., 2010 , Tilburgs et al., 2008), with about $55 \%$ of these cells at term in turn being putative Helios $^{+} \mathrm{nT}_{\text {Reg }}$ cells, and $45 \%$ being putative Helios- ${ }^{-1} \mathrm{~T}_{\text {Reg }}$ cells (Hsu et al., 2012). In humans, $\mathrm{T}_{\text {Reg }}$ cell frequen- 
cies have also been noted to be higher in the decidua than in the blood (Dimova et al., 2011, Mjosberg et al., 2010, Nagamatsu et al., 2011, Sasaki et al., 2004, Schumacher et al., 2009, Tilburgs et al., 2008, Tilburgs et al., 2006).

These data have an important caveat, however, since they were generated via flow cytometric analyses of disaggregated tissues. Namely, it is currently unknown how many of the T cells visualized in this matter are present within the tissue parenchyma versus the blood that is flowing through the tissue. In mice, this issue has been highlighted by our recent data discussed below demonstrating that $T_{H} 1$ cells and CTLs are actively prevented from extravasating into the decidua (Nancy et al., 2012). Indeed, using a technique we developed for discriminating intravascular from extravascular leukocytes in the decidua (Tagliani et al., 2011), we have found that the majority of the CD4 and CD8 T cells isolated from non-perfused decidua on E8.5 are actually intravascular under steady state conditions (Nancy and Erlebacher, unpublished data). It is unclear whether vascular perfusion is able to remedy this problem, as many leukocytes within the mouse decidua are adherent to the endothelium (Kruse et al., 1999). Judging from work in rats, these leukocytes are likely to remain even after vascular perfusion (Welsh and Enders, 1985).

A related interpretative issue concerns the comparison made frequently between the lymphocyte subset composition of peripheral blood of a pregnant woman and the composition of the woman's decidua. This comparison, in which the over-representation of a given subset is sometimes taken to imply the existence of local mechanisms that directly enhance that subset's recruitment or survival have not sufficiently considered the fact that naïve T cells, which lack tissue-homing chemokine receptors (e.g. CXCR3, CCR4, CCR5, CCR6), enter non-lymphoid peripheral tissues relatively poorly. For example, in a recent study on pregnant women at term, naïve (CD45RA $\left.{ }^{+}\right)$CD8 $T$ cells were shown to comprise $\sim 50 \%$ of all CD8 T cells in the blood, but only $\sim 5 \%$ of CD8 T cells in the decidua, with these latter cells including ones that might actually be intravascular (Tilburgs et al., 2010b). Similar results have been obtained for both CD4 and CD8 T cells in studies of the first trimester (Saito et al., 1994, Slukvin et al., 1996). These data imply that that all differentiated $T$ cell subsets will, without any specific recruitment mechanism, appear enriched within the decidua compared to the blood when cell numbers are expressed as proportions of respective total CD4 or CD8T cells. Despite some evidence pointing to the involvement of specific chemoattractants (Schumacher et al., 2009), this issue is particularly relevant to suggestions that $T_{\text {Reg }}$ cells are actively recruited to the human maternal-fetal interface (Schumacher et al., 2009, Tilburgs et al., 2008, Tilburgs et al., 2006).

\section{Antigen specificity and locations of antigen presentation}

Two of the most persistent and difficult questions regarding the biology of decidual T cells are whether the cells have specificity for placental antigens, and if so, where they encounter these antigens. The former question is far from trivial given the existence of resident memory cells and the well-known property of effector memory $\mathrm{T}$ cells to continuously traffic through peripheral tissues even in the absence of local inflammation or infection. $T_{\text {Reg }}$ cells also have promiscuous homing properties and are thought to populate all tissues to some extent at steady state (Campbell and Koch, 2011). Thus, it is entirely conceivable that a large fraction of decidual $\mathrm{T}$ cells do not have placental specificity but rather populate the decidua either because they just happen to be migrating through this tissue in an antigen non-specific fashion, or because they are the same cells that were present in the endometrium at the time of implantation. These possibilities are also supported by the lack of data showing that maternal $\mathrm{T}$ cells are robustly activated to placental antigens, as discussed further below, as well as data indicating that certain $\mathrm{T}$ cell subsets are actively prevented from extravasating into the decidua, also discussed below.

The question of where $\mathrm{T}$ cells encounter placental antigens, while understood to a much greater extent, still has unresolved aspects. In mice, the uterine draining lymph nodes (LN) are sites of placental antigen presentation, but this is surprisingly not the result of DC migration from the decidua. Rather, decidual DC become trapped within the tissue, and placental antigens instead are disseminated in cell-free form both via the regional lymphatics as well as through the blood, which gives them access to the spleen and all LN throughout the body (Collins et al., 2009, Erlebacher et al., 2007, Moldenhauer et al., 2009, Rowe et al., 2012). Ensuing antigen presentation by the antigen presenting cells (APCs) that reside within these secondary lymphoid organs is ultimately nonimmunogenic, however, as effector T cells are not generated from naïve precursors. Instead, the responding T cells are largely deleted as they simultaneously undergo multiple rounds of cell division. This work has been based upon the use of transgenic mice that express model antigens as surrogate fetal/placental antigens in order to clearly detect antigen-specific $\mathrm{T}$ cell responses, but it is assumed that findings also apply to endogenous placental antigens (for review, see Moldenhauer et al., 2010). In the case of at least one model antigen, it has recently been shown that the systemic CD4 T cell response can also involve conversion into iT Reg $_{\text {cells, but }}$ the number of such cells generated in this matter is at maximum on the order of 1000 cells per mouse (Rowe et al., 2012).

The upshot of this work is that it might be incredibly difficult to detect maternal T cells specifically responding to placental antigens in humans, especially if blood alone is analyzed. In one recent attempt, CD8 T cells specific for male HY minor histocompatibility antigen were indeed detected in the blood of pregnant women bearing male concepti, but the cells were only detectable in half of the relevant pregnancies and their percentage (of total CD8 T cells) was on average only $0.043 \%$ after 10 days of in vitro peptide stimulation (Lissauer et al., 2012). Interestingly, the cells that grew out had an effector memory phenotype. In another study, a mother/ child mismatch in human leukocyte antigen- (HLA-) $\mathrm{C}$, which is one of the classical MHC class I molecules in humans, was found to enrich the frequency of CD25 dim (i.e. activated or memory) decidual CD4 T cells by about $10 \%$, an observation that was attributed to the presentation of paternal HLA-C-derived peptides by maternal APCs (Tilburgs et al., 2009a). HLA-C-specific CD4 $T$ cells were not directly identified, however, and no change was observed in the frequency of decidual CD28- (effector or effector/ memory) CD8 T cells.

Indeed, recent work in mice has complicated even the idea that the expanded numbers of $T_{\text {Reg }}$ cells observed systemically during both mouse and human gestation represent the aggregate response of a large number of CD4 T cell clones synchronously converting to $\mathrm{iT}_{\text {Reg }}$ cells in response to shed placental antigen. Specifically, it was found that treatment of non-pregnant mice with 
the pregnancy hormone progesterone, given at doses to achieve serum levels similar to what occur at midgestation, induced the same systemic $\sim 2$-4-fold expansion of $T_{\text {Reg }}$ cells typically seen during mouse pregnancy (Mao et al., 2010). Conversely, this study also revealed that $T_{\text {Reg }}$ cells expand in a progesterone receptordependent fashion in mice rendered "pseudopregnant," which is a temporary hormonal state induced by the act of copulation alone (without actual embryo implantation) and associated with elevated progesterone production by the ovary. Thus, expanded systemic $\mathrm{T}_{\text {Reg }}$ cell numbers during both mouse and human pregnancy might largely reflect an antigen non-specific effect of progesterone rather than specific induction by placental antigens. Of note, however, another study has shown no effect of progesterone on $\mathrm{T}_{\text {Reg }}$ cell numbers in mice (Zhao et al., 2007).

Importantly, however, it remains possible that decidual APCs present placental antigen within the decidua itself. Indeed, CD83 ${ }^{+}$ DCs in the first trimester human decidua form clusters with decidual T cells (Kammerer et al., 2000), while CD14+ DC-SIGN ${ }^{+}$cells, which are thought to be a specialized macrophage subset with antigen presenting capacity (Erlebacher, 2013a, Nagamatsu and Schust, 2010), have been found in close association with decidual $T_{\text {Reg }}$ cells (Hsu et al., 2012). If these spatial proximities reflect ongoing antigen presentation, however, it remains unclear the extent to which the responding $T$ cells are naïve given the exclusion of naïve $T$ cells from peripheral tissues and the low proportion of naïve T cells in the human decidua (Saito et al., 1994, Slukvin et al., 1996, Tilburgs et al., 2010b). Indeed, the current set of data in mice strongly argues against the intra-decidual presentation of placental antigens to at least naïve CD8 T cells, since such cells can be seen responding to a surrogate placental antigen in the spleen and uterine draining LN without any concurrent response within the decidua itself (Erlebacher et al., 2007). Thus, it is important to consider the alternative possibility that the intra-decidual presentation of placental Ag serves to reinforce the activation of placenta-specific T cells that were first exposed to antigen elsewhere. This possibility is consistent with the demonstrated systemic generation of $\mathrm{iT}_{\text {Reg }}$ cells specific for shed placental antigens (Rowe et al., 2012) followed by the homing of these cells to the decidua. Given recent data that the maternal-fetal interface is normally colonized at low levels with a variety of microbes (Stout et al., 2013), it is also possible that decidual APCs present microbe-derived peptides, perhaps as part of a mechanism to combat decidual infection.

\section{Recruitment}

Another dimension to the issue of the composition and function of decidual $\mathrm{T}$ cells comes from recent work from our laboratory showing that activated $\mathrm{T}_{H} 1$ cells and CTLs are actively excluded from the mouse decidua (Nancy et al., 2012). This exclusion prevented antigen-specific fetal loss but itself was not antigen-specific. Rather, it was linked to an epigenetic program activated in differentiating decidual stromal cells (DSCs) that silenced expression of the Cxcl9, Cxcl10, Cxcl11 and Ccl5 genes that encode the key $\mathrm{T}_{H} 1$ cell- and CTL-attracting chemokines CXCL9, CXCL10, CXLC11, and CCL5 discussed above.

In addition to suggesting a major reason why the fetus is not rejected by the maternal immune system, these results demonstrated that epigenetic pathways active in the stromal compartment of the mouse decidua play a major role in controlling $T$ cell subset population dynamics at the maternal-fetal interface. Two pressing questions, therefore, are whether similar pathways are active in humans, and, if so, the extent to which they influence $T$ cell composition of the human decidua in various physiological and pathophysiological settings. In particular, the existence of chemokine gene silencing pathways raises the possibility that the apparent relative proportions of $T$ cell subsets in the decidua in normal pregnancy might not be the consequence of the active, specific recruitment of certain $T$ cell subsets over others, or the selective proliferation, survival or retention of these subsets, but rather because $T$ cell subsets strictly dependent upon CXCL9, CXCL10, CXCL11 and CCL5 for peripheral tissue recruitment are excluded. Indeed, demonstration that CXCL9, CXCL10, CXCL11 and CCL5 are silenced in human decidual stromal cells would suggest that the $T_{H} 1$ cells that populate the human decidua at relatively high numbers are present from the time of implantation and may in fact represent resident memory cells that lack specificity for placental antigen.

\section{Regulation}

The decidua-specific factors and pathways that regulate decidual $T$ cell behavior are very poorly understood, and several promising ideas have not panned out in a robust fashion due to the absence of pregnancy phenotypes in gene-deficient mouse models. These include the proposals that the death ligand FasL, the negative costimulatory molecule PD-L1, and the tryptophan catabolizing enzyme idoleamine 2,3-dioxygenase, which are all expressed at the maternal-fetal interface would respectively kill, render inactive, or starve infiltrating effector T cells (Baban et al., 2004, Chaouat and Clark, 2001, Taglauer et al., 2009). In contrast, there is mounting evidence that the multifunctional carbohydrate-binding protein Galectin-1 may locally regulate decidual T cell behavior to promote a uterine environment supportive of pregnancy (for review see Barrientos et al., 2013). Consistent with this possibility, female mice deficient in Galectin-1 show higher rates of fetal loss in allogeneic but not syngeneic pregnancies (Blois et al., 2007). Galectin-1 has also been shown to be co-localized to clusters of $\mathrm{T}$ cells within the human decidua that are undergoing apoptosis (Kopcow et al., 2008), suggesting a possible role in regulating intradecidual $T$ cell survival. As discussed further below, decidual NK cells have also recently been shown to repress $T_{H} 17$ cells through their production of IFN $\gamma$ (Fu et al., 2013). Lastly, as also discussed further below, decidual $\mathrm{T}_{\text {Reg }}$ cells are thought to attenuate the activity of decidual effector $\mathrm{T}$ cells.

\section{Functions and pathological associations}

\section{Implantation}

At present, it is technically difficult to perform intrauterine T cell ablations in mice, and ethical concerns preclude experimentation on pregnant women. Consequently, our current understanding of the function of decidual $\mathrm{T}$ cell subsets during pregnancy has largely been inferential, as it derives from knowledge about the function of each subset in non-uterine tissues and discoveries of associations between human pregnancy pathologies and changes in a subset's prevalence within the decidua. Examples of this approach will be discussed further below. One emerging exception to the current state of ambiguity, however, comes from work 
suggesting that $\mathrm{T}_{\text {Reg }}$ cells play an important role in preparing the endometrium for implantation (for review, see Robertson et al., 2013). This idea has been gaining support from multiple studies in mice showing that $T_{\text {Reg }}$ cell deficiency in the peri-implantation period, induced experimentally via a variety of means, causes either implantation failure or embryo resorption soon after implantation. In some studies (Aluvihare et al., 2004, Shima et al., 2010) (but not others; (Teles et al., 2013a), this failure occurs in allogeneic but not syngeneic mating combinations, suggesting that $T$ cell responses to alloantigens present in semen might be important for implantation. Consistent with this possibility, maternal CD8 T cells undergo a transient wave of proliferation in the uterine LN following copulation in response to a surrogate seminal antigen (Moldenhauer et al., 2009). Interestingly, in this model, seminal fluid rather than spermatozoa was the antigen-containing material.

A specific, intrauterine requirement for $T_{\text {Reg }}$ cells in implantation was first suggested by the observation that CD4 ${ }^{+} \mathrm{CD}^{2} 5^{+} \mathrm{FOXP3}^{+}$ $T_{\text {Reg }}$ cell frequencies also transiently increase in the uterine $L N$ on E3.5 (but not in the non-uterine LN), concurrent with the wave of antigen-induced $\mathrm{T}$ cell proliferation described above (Guerin et al., 2011). In addition, FOXP3 ${ }^{+}$cells, which are presumably also $\mathrm{T}_{\text {Reg }}$ cells, were found to be greater in number in the uteri of mice on E3.5 of pregnancy as compared to the uteri of mice in estrous. Both of these phenomena required seminal plasma, which, pro-

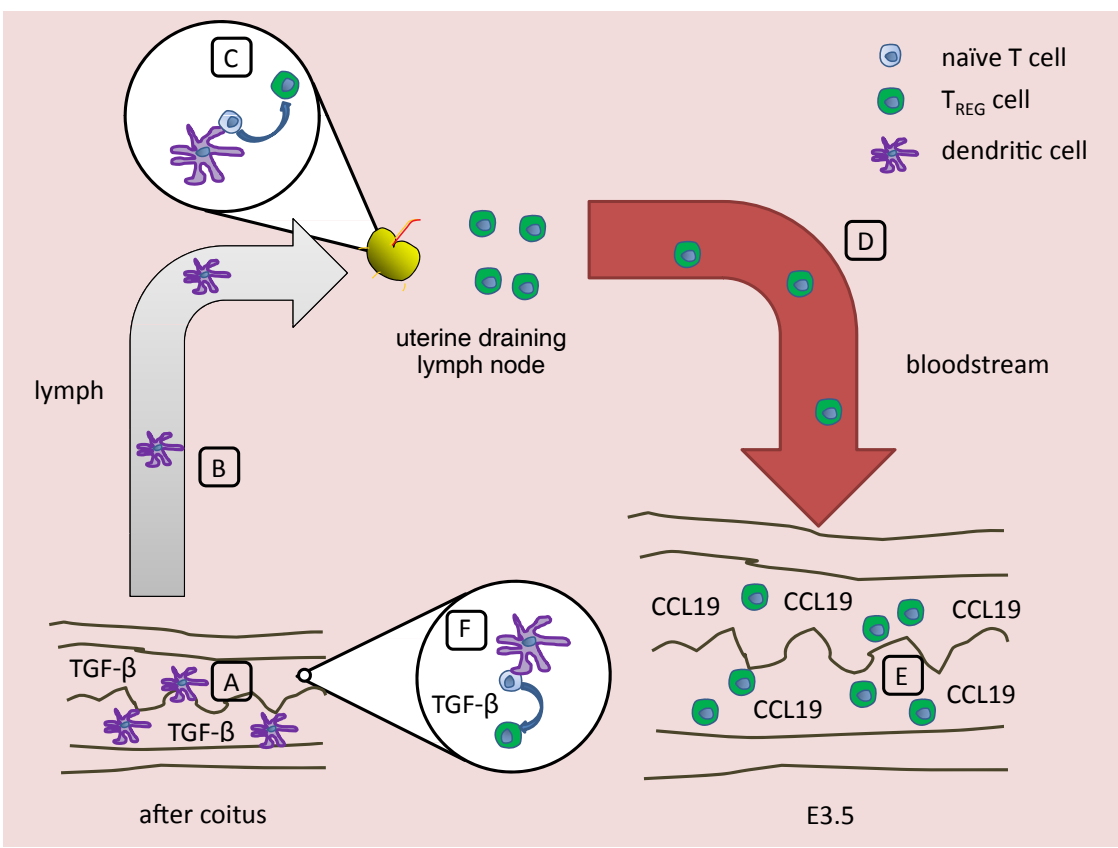

Fig. 2. Regulatory CD4 $T$ cell $\left(T_{\text {Reg }}\right.$ cell) generation in response to semen in the preimplantation mouse uterus. Two complementary mechanisms are shown; the evidence for the first is discussed in the text. (A-E) Under the influence of seminal fluid rich in TGF- $\beta$ (A), $D C$ s ingest and process seminal fluid antigens and then migrate via lymphatic vessels (B) to the uterine $L N$. In these $L N$, they present seminal fluid antigens and convert responding naive T cells into $T_{\text {Reg }}$ cells due to the influence of TGF- $\beta$ (C). Of note, it is unclear whether the TGF- $\beta$ that acts during this phase of the response is derived from seminal fluid, or is produced by maternal cells. Once generated, the $T_{\text {Reg }}$ cells migrate via the blood back to the uterus (D), possibly attracted by CCL19 induced by uterine epithelial cells in response to semen (E). (A,F) Alternatively, uterine DCs might present seminal fluid antigens to naive $T$ cells within the uterus itself, which locally induces iT $T_{\text {Reg }}$ cell generation due to the high levels of TGF- $\beta$ in seminal fluid. vocatively, is rich in the $T_{\text {Reg }}$ cell-inducing cytokine TGF- $\beta$ (Sharkey et al., 2012). Copulation also induced expression of the CCL19 (o be actor for uterine $\mathrm{T}_{\text {Reg }}$ cells (Guerin et al., 2011). In another study, mice deficient in CCR7, the receptor for CCL19, cked uterine Tregs and also showed reduced fertility (Teles in mice lacking $T_{\text {Reg }}$ cells.

Together these data suggest a scenario whereby $T_{\text {Reg }}$ cells, induced in the uterine $L N$ in response to semen and seminal antigens, me back to the uterus where they prepare the endometrium for resumably, the $\mathrm{T}_{\text {Reg }}$ cells in part act to dampen uterine inmation, which is induced by semen (De et al., 1991). However, recognition is important for post-copulation $T$ cell expansion and ultimate $T_{\text {Reg }}$ cell function in the uterus needs to be determined. This is a key issue because postulating a specific requirement for $\mathrm{iT}_{\text {Reg }}$ specifically deficient in these cells (Samstein et al., 2012). Second, it will be important to determine whether the $\mathrm{T}_{\text {Reg }}$ cells that expand in the uterine LN following insemination selectively home to the uterus, as this would imply the existence of specific, and currently unappreciated, uterinehoming pathways. Indeed, it remains possible that the requirement for $\mathrm{CCR} 7$ in generating the cells actually reflects the CCR7 dependence of DC emigration from the reproductive tract (Collins et al., 2009), which is expected to be necessary for the presentation of seminal antigens in the draining $L N$. Third, the idea that the anti-inflammatory effects of $T_{\text {Reg }}$ cells are important for preparing the uterus for implantation needs to be reconciled with the growing sense that a modest amount of uterine inflammation promotes implantation (Dekel et al., 2010).

Lastly, and most importantly, the current set of data does not resolve whether $\mathrm{T}_{\text {Reg }}$ cells act locally within the uterus, or systemically, or both. Indeed, $\mathrm{T}_{\text {Reg }}$ depletion induces systemic inflammation (Kim et al., 2007), and the peri-implantation period is particularly sensitive to inflammation-induced ovarian insufficiency (Erlebacher et al., 2004). Thus, it remains possible that implantation failure in the absence of sufficient $T_{\text {Reg }}$ cell function systemically is due to impaired progesterone production by the corpus luteum. In fact, the requirement for $\mathrm{T}_{\text {Reg }}$ cells during the peri-implantation period might even reflect a crucial role for $T_{\text {Reg }}$ cells within the ovary itself, a possibility suggested by work in cows showing that the luteolytic effect of prostaglandin $\mathrm{PGF}_{2 \mathrm{a}}$ is associated with reductions in ovarian $\mathrm{T}_{\text {Reg }}$ cell numbers (Poole and Pate, 2012).

\section{Preeclampsia and spontaneous abortion}

Potential roles for decidual $\mathrm{T}_{\text {Reg }}$ cells have also emerged from studies on the pathogenesis of pre- 
eclampsia and spontaneous abortion (for review, see (Cerdeira et al., 2012, Ernerudh et al., 2011)). Stimulated by reports of reduced $T_{\text {Reg }}$ cell frequencies in the peripheral blood of pregnant women with preeclampsia compared to control pregnant women (DarmochwalKolarz et al., 2007, Prins et al., 2009, Santner-Nanan et al., 2009, Sasaki et al., 2007, Toldi et al., 2012) (a finding not replicated with other cohorts; Hu et al., 2008, Paeschke et al., 2005), it was initially suggested that $\mathrm{T}_{\text {Reg }}$ frequencies at the maternal-fetal interface were also reduced in preeclampsia (Quinn et al., 2011, Sasaki et al., 2007). A recent report failed to reproduce this observation, but instead revealed that preeclamptic patients showed specific reductions decidual frequencies of Helios- FOXP3+ CD25+ CD4 ${ }^{+}$ cells, which presumably represent $\mathrm{iT}_{\text {Reg }}$ cells (Hsu et al., 2012). This defect was furthermore linked to an altered phenotype of decidual DC-SIGN ${ }^{+}$APCs, which were found to be located in proximity to decidual $\mathrm{T}_{\text {Reg }}$ cells. Reduced decidual $\mathrm{T}_{\text {Reg }}$ cell frequency or function has also been reported in cases of spontaneous abortion (Inada et al., 2013, Sasaki et al., 2004, Schumacher et al., 2009, Wang et al., 2010), sometimes in association with increased $T_{H} 17$ cell frequencies (Wang et al., 2010).

Given the well-known immunosuppressive functions of $\mathrm{T}_{\text {Reg }}$ cells, these data together suggest a scenario in which $\mathrm{T}_{\text {Reg }}$ cells expand within the decidua, potentially as the result of the local presentation of placental antigens by decidual APCs, in order to limit effector $T$ cell activity at the maternal-fetal interface (Ernerudh et al., 2011). Without such a limit, effector $T$ cells (i.e. $T_{H} 1$ cells, $\mathrm{T}_{\mathrm{H}} 17$ cells and CTLs) are freer to induce pregnancy pathologies ranging from first trimester fetal loss to inadequate spiral artery remodeling. Exact effector mechanisms for a given pathology, however, are unknown and an important area of research. In addition, $\mathrm{T}_{\text {Reg }}$ cells might also generally limit decidual inflammation through antigen non-specific mechanisms. This latter possibility is consistent with the cells' secretion of anti-inflammatory factors such as IL-10 and TGF- $\beta$, which will have broad effects, as well as with emerging data in mice discussed above that uterine $T_{\text {Reg }}$ cells play an anti-inflammatory role in preparing the uterus for embryo implantation. Such a latter role would obviously be independent of placental antigen exposure. Importantly, elevated proportions of decidual $\mathrm{T}_{\mathrm{H}} 17$ cells per se have been linked to the pathogenesis of spontaneous abortion (Nakashima et al., 2010, Wang et al., 2010), and recent work in both mice and humans (Fu et al., 2013) suggests that decidual NK cells, through their production of IFN $\gamma$, are also capable of suppressing decidual $\mathrm{T}_{H} 17$ cell accumulation. Thus, elevated decidual $T_{H} 17$ cell frequencies in spontaneous abortion have also been associated with low NK cell numbers (Fu et al., 2013). Together, these data build upon older work and have led to a revised Th1/Th2/Th17/T Reg cell paradigm for pregnancy success (Saito et al., 2010).

\section{Villitis of unknown etiology and chronic deciduitis}

Overt, histologically apparent T cell accumulations, akin to those seen with organ transplant rejection, are not findings typically associated with preeclampsia or spontaneous abortion. Thus, the contribution of $\mathrm{T}$ cells to these pathologies is thought to be mainly due to changes in $\mathrm{T}$ cell subset proportions and altered $\mathrm{T}$ cell functions. In contrast, villitis of unknown etiology (VUE), chronic deciduitis, and chronic chorioamnionitis are three histological findings of the third trimester placenta where maternal T cells do accumulate at the maternal-fetal interface (Erlebacher, 2013a).
Given the greater amount of relevant literature, we will discuss the pathogenesis and significance of VUE, with the recognition that the set of questions this lesion raises also applies to chronic deciduitis and chronic chorioamnionitis.

VUE affects $5-15 \%$ of all births and is characterized by focal accumulations of maternal T cells, comprised of both CD4 and CD8 T cells, as well as fetal macrophages (i.e. Hofbauer cells) (for reviews, see Redline, 2007, Tamblyn et al., 2013). The lesions are primarily located in the distal placental villi, but it has been suggested that they arise from leukocytes that have first infiltrated into the decidua before spreading vertically via the anchoring villi to reach the villus tree. Its origin is not thought to be infectious. From a clinical viewpoint, VUE is an interesting lesion since its incidence is increased in several complications of human pregnancy, including idiopathic preterm birth and intrauterine growth restriction. Its causal relationship with these pregnancy complications is at present unclear. The lesion is associated with increased placental mRNA expression of CXCL9, CXCL10, CXCL11 and CCL5 (Freitag et al., 2013, Kim et al., 2009), as well as focal expression of CXCL9, CXCL10, and CCL5 protein at the sites of leukocyte accumulation (Kim et al., 2009). $\mathrm{T}_{H} 1$ cells are thought to primarily comprise the CD4 T cell component of the response, while the CD8 T cells are thought to be CTLs.

From a basic viewpoint, VUE is also interesting because its histological features are what might be expected if maternal $T$ cells were to be rejecting the placenta. Considering this possibility raises the interesting question of the antigen specificity of the infiltrating T cells, which remains unknown. This is a key question since it speaks to underlying pathogenic mechanisms. If the T cells are specific for placental antigens, then there must have been at some point a breakdown in those pathways that normally prevent the immunogenic presentation of placental antigens to maternal T cells. In addition, there must have been a breakdown in mechanisms that prevent $T_{H} 1$ cell and CTL infiltration into the decidua and placenta. Indeed, the focal nature of VUE in itself points to the potential existence of such mechanisms, since otherwise such activated $T$ cells should show a diffuse pattern of infiltration. Indeed, we have previously conjectured that focal dysregulation of the epigenetic pathways that silence $\mathrm{Cxc} / 9, \mathrm{Cxc} / 10$, and $\mathrm{Ccl} / 5$ expression in mouse DSCs, if these pathways are also active in human DSCs, might underlie at least the decidual component of VUE (Erlebacher, 2013a). It also is possible that maternal T cell directly enter the placental tree as the result of a focal damage or because syncytiotrophoblasts (which form the cellular layer of the villus tree in contact with maternal blood) have upregulated certain key adhesion molecules (Redline, 2007, Tamblyn et al., 2013)).

If, on the other hand, the infiltrating T cells in VUE are not specific for placental antigens, then work on underlying pathogenic mechanisms needs to consider only how these T cells gain access to the decidua and placenta, and could consider the same set of hypotheses as if they did have placental specificity. Interestingly, the possibility that the infiltrating T cells are bystanders (with respect to fetal and placental antigens) raises the possibility that they were generated at distal sites, perhaps in response to infection.

Importantly, although indirect presentation pathways are thought to mediate $\mathrm{T}$ cell recognition of placental antigens under physiological conditions in both mice and humans, as discussed above, it remains possible that the $T$ cells within VUE lesions are specific for intact paternal MHC molecules. In the case of CD8 T cells, the 
cells might be interacting directly with paternal HLA-C molecules expressed not only by extravillous trophoblasts (for those areas of the lesion within the decidua) but also with all MHC class I molecules expressed by the fetus-derived non-trophoblastic stromal constituents of the villi including fibroblasts, endothelial cells and Hofbauer cells. In the case of CD4 T cells, the cells might be interacting directly with Hofbauer cells, which express MHC class II molecules in VUE lesions. If such directly alloreactive maternal $T$ cells are indeed constituents of VUE lesions, the question again arises of how these cells first become activated.

\section{Conclusions}

Importantly, the above pathological scenarios view effector Tcells within the decidua as having a negative impact upon pregnancy success. This idea is certainly more likely if a large proportion of these $T$ cells turn out to have specificity for placental antigens. However, recent work suggesting that the human maternal-fetal interface is normally colonized with a wide variety of bacteria (Stout et al., 2013) suggests that effector T cells within the decidua might perform a positive function in controlling infection. If this is true, then this function must be very finely tuned so that the response, on the one hand, is sufficient to prevent progression to pregnancy endpoints such as acute infectious chorioamnionitis, while on the other hand is not so robust that the attendant inflammation in fighting the infection leads to pregnancy complications such as preterm labor secondary to non-infectious chorioamnionitis. As discussed further elsewhere (Erlebacher, 2013a, Tilburgs and Strominger, 2013), the existence of intra-decidual mechanisms to limit maternal $T$ cell responses against the placenta might also explain why the decidua is susceptible to infection by certain organisms such as Listeria monocytogenes and cytomegalovirus.

Indeed, how intradecidual T cell behavior is balanced in order to accommodate the competing demands of reproduction and host defense can now be viewed as a key question facing research on the biology of decidual T cells. As discussed above, other important unresolved questions include the pathways that regulate intradecidual T cell function, the antigen specificity of decidual T cells, and the degree to which dysregulation of decidual T cells function or migration are causative pathogenic factors in human pregnancy complications. It is hoped that the current surge in interest in this critical area of reproductive immunology will lead to insights with potential impact on human reproductive health.

\section{Acknowledgements}

Work in the Erlebacher lab is supported by grants from the $\mathrm{NIH}$ (RO1CA168755 and RO1-Al106745), The American Cancer Society (RSG-10158-01-LIB), and The March of Dimes (\#6-FY13-80).

\section{References}

AKIMOVA, T., BEIER, U.H., WANG, L., LEVINE, M.H. and HANCOCK, W.W. (2011). Helios expression is a marker of T cell activation and proliferation. PLOS One 6: e24226.

ALUVIHARE, V.R., KALLIKOURDIS, M. and BETZ, A.G. (2004). Regulatory T cells mediate maternal tolerance to the fetus. Nat Immunol 5: 266-271.

BABAN, B., CHANDLER, P., MCCOOL, D., MARSHALL, B., MUNN, D.H. and MELLOR, A.L. (2004). Indoleamine 2,3-dioxygenase expression is restricted to fetal trophoblast giant cells during murine gestation and is maternal genome specific. $J$ Reprod Immunol 61: 67-77.
BARRIENTOS, G., FREITAG, N., TIRADO-GONZALEZ, I., UNVERDORBEN, L., JESCHKE, U., THIJSSEN, V.L. and BLOIS, S.M. (2013). Involvement of galectin-1 in reproduction: past, present and future. Hum Reprod Update 20: 175-193.

BLOIS, S.M., ILARREGUI, J.M., TOMETTEN, M., GARCIA, M., ORSAL, A.S., CORDO-RUSSO, R., TOSCANO, M.A., BIANCO, G.A., KOBELT, P., HANDJISKI, B. et al., (2007). A pivotal role for galectin-1 in fetomaternal tolerance. Nat Med 13: $1450-1457$.

BULMER, J.N., MORRISON, L., LONGFELLOW, M., RITSON, A. and PACE, D. (1991). Granulated lymphocytes in human endometrium: histochemical and immunohistochemical studies. Hum Reprod 6: 791-798.

BULMER, J.N., WILLIAMS, P.J. and LASH, G.E. (2010). Immune cells in the placental bed. Int J Dev Biol 54: 281-294.

CAMPBELL, D.J. and KOCH, M.A. (2011). Phenotypical and functional specialization of FOXP3+ regulatory T cells. Nat Rev Immunol 11: 119-130.

CERDEIRA, A.S., KOPCOW, H.D. and KARUMANCHI, S.A. (2012). Regulatory T cells in preeclampsia: some answers, more questions? Am J Pathol 181: 1900-1902.

CHAOUAT, G. and CLARK, D.A. (2001). FAS/FAS ligand interaction at the placental interface is not required for the success of allogeneic pregnancy in anti-paternal MHC preimmunized mice. Am J Reprod Immunol 45: 108-115.

COLLINS, M.K., TAY, C.S. and ERLEBACHER, A. (2009). Dendritic cell entrapment within the pregnant uterus inhibits immune surveillance of the maternal/fetal interface in mice. J Clin Invest 119: 2062-2073.

CROY, B.A., CHEN, Z., HOFMANN, A.P., LORD, E.M., SEDLACEK, A.L. and GERBER, S.A. (2012). Imaging of vascular development in early mouse decidua and its association with leukocytes and trophoblasts. Biol Reprod 87: 125.

DARMOCHWAL-KOLARZ, D., SAITO, S., ROLINSKI, J., TABARKIEWICZ, J., KOLARZ, B., LESZCZYNSKA-GORZELAK, B. and OLESZCZUK, J. (2007). Activated T lymphocytes in pre-eclampsia. Am J Reprod Immunol 58: 39-45.

DE, M., CHOUDHURI, R. and WOOD, G.W. (1991). Determination of the number and distribution of macrophages, lymphocytes, and granulocytes in the mouse uterus from mating through implantation. J. Leukocyte Biol. 50: 252-262.

DEKEL, N., GNAINSKY, Y., GRANOT, I. and MOR, G. (2010). Inflammation and implantation. Am J Reprod Immunol 63: 17-21.

DIMOVA, T., NAGAEVA, O., STENQVIST, A.C., HEDLUND, M., KJELLBERG, L., STRAND, M., DEHLIN, E. and MINCHEVA-NILSSON, L. (2011). Maternal Foxp3 expressing CD4+ CD25+ and CD4+ CD25- regulatory T-cell populations are enriched in human early normal pregnancy decidua: a phenotypic study of paired decidual and peripheral blood samples. Am J Reprod Immunol 66 Suppl 1:44-56.

ERLEBACHER, A. (2013a). Immunology of the maternal-fetal interface. Annu Rev Immunol 31: 387-411.

ERLEBACHER, A. (2013b). Mechanisms of T cell tolerance towards the allogeneic fetus. Nat Rev Immunol 13: 23-33.

ERLEBACHER, A., VENCATO, D., PRICE, K.A., ZHANG, D. and GLIMCHER, L.H. (2007). Constraints in antigen presentation severely restrict $T$ cell recognition of the allogeneic fetus. J Clin Invest 117: 1399-1411.

ERLEBACHER, A., ZHANG, D., PARLOW, A.F. and GLIMCHER, L.H. (2004). Ovarian insufficiency and early pregnancy loss induced by activation of the innate immune system. J Clin Invest 114: 39-48.

ERNERUDH, J., BERG, G. and MJOSBERG, J. (2011). Regulatory T helper cells in pregnancy and their roles in systemic versus local immune tolerance. $\mathrm{Am} \mathrm{J}$ Reprod Immunol 66 Suppl 1: 31-43.

FREEMAN, B.E., HAMMARLUND, E., RAUE, H.P. and SLIFKA, M.K. (2012). Regulation of innate CD8+ T-cell activation mediated by cytokines. Proc Natl Acad Sci USA 109: 9971-9976.

FREITAG, L., VON KAISENBERG, C., KREIPE, H. and HUSSEIN, K. (2013). Expression analysis of leukocytes attracting cytokines in chronic histiocytic intervillositis of the placenta. Int J Clin Exp Pathol 6: 1103-1111.

FU, B., LI, X., SUN, R., TONG, X., LING, B., TIAN, Z. and WEI, H. (2013). Natural killer cells promote immune tolerance by regulating inflammatory $\mathrm{TH} 17$ cells at the human maternal-fetal interface. Proc Natl Acad Sci USA 110: E231-E240.

GOTTSCHALK, R.A., CORSE, E. and ALLISON, J.P. (2012). Expression of Helios in peripherally induced Foxp3+ regulatory T cells. J Immunol 188: 976-980.

GUERIN, L.R., MOLDENHAUER, L.M., PRINS, J.R., BROMFIELD, J.J., HAYBALL, J.D. and ROBERTSON, S.A. (2011). Seminal Fluid Regulates Accumulation of FOXP3+ 
Regulatory T Cells in the Preimplantation Mouse Uterus Through Expanding the FOXP3+ Cell Pool and CCL19-Mediated Recruitment. Biol Reprod. 85: 397-408.

HSU, P., SANTNER-NANAN, B., DAHLSTROM, J.E., FADIA, M., CHANDRA, A., PEEK, M. and NANAN, R. (2012). Altered decidual DC-SIGN+ antigen-presenting cells and impaired regulatory T-cell induction in preeclampsia. Am J Pathol 181: 2149-2160.

HU, D., CHEN, Y., ZHANG, W., WANG, H., WANG, Z. and DONG, M. (2008). Alteration of peripheral $C D 4+C D 25$ + regulatory $T$ lymphocytes in pregnancy and pre-eclampsia. Acta Obstet Gynecol Scand 87: 190-194.

INADA, K., SHIMA, T., NAKASHIMA, A., AOKI, K., ITO, M. and SAITO, S. (2013). Characterization of regulatory $T$ cells in decidua of miscarriage cases with abnormal or normal fetal chromosomal content. J Reprod Immunol 97: 104-111.

KAMMERER, U., SCHOPPET, M., MCLELLAN, A.D., KAPP, M., HUPPERTZ, H.I., KAMPGEN, E. and DIETL, J. (2000). Human decidua contains potent immunostimulatory CD83(+) dendritic cells. Am J Pathol 157: 159-69.

KIM, J.M., RASMUSSEN, J.P. and RUDENSKY, A.Y. (2007). Regulatory T cells prevent catastrophic autoimmunity throughout the lifespan of mice. Nat Immuno/8: 191-197.

KIM, M.J., ROMERO, R., KIM, C.J., TARCA, A.L., CHHAUY, S., LAJEUNESSE, C., LEE, D.C., DRAGHICI, S., GOTSCH, F., KUSANOVIC, J.P. et al., (2009). Villitis of unknown etiology is associated with a distinct pattern of chemokine up-regulation in the feto-maternal and placental compartments: implications for conjoint maternal allograft rejection and maternal anti-fetal graft-versus-host disease. J Immunol 182: 3919-3927.

KING, A., BURROWS, T.D., HIBY, S.E., BOWEN, J.M., JOSEPH, S., VERMA, S., LIM, P.B., GARDNER, L., LE BOUTEILLER, P., ZIEGLER, A. et al., (2000). Surface expression of HLA-C antigen by human extravillous trophoblast. Placenta 21: 376-387.

KOPCOW, H.D., ROSETTI, F., LEUNG, Y., ALLAN, D.S., KUTOK, J.L. and STROMINGER, J.L. (2008). T cell apoptosis at the maternal-fetal interface in early human pregnancy, involvement of galectin-1. Proc Natl Acad Sci USA 105: 18472-18477.

KRUSE, A., MERCHANT, M.J., HALLMANN, R. and BUTCHER, E.C. (1999). Evidence of specialized leukocyte-vascular homing interactions at the maternal/fetal interface. Eur J Immunol 29: 1116-1126.

LISSAUER, D., PIPER, K., GOODYEAR, O., KILBY, M.D. and MOSS, P.A. (2012). Fetal-specific CD8+ cytotoxic $T$ cell responses develop during normal human pregnancy and exhibit broad functional capacity. J Immunol 189: 1072-1080.

MADEJA, Z., YADI, H., APPS, R., BOULENOUAR, S., ROPER, S.J., GARDNER, L., MOFFETT, A., COLUCCI, F. and HEMBERGER, M. (2011). Paternal MHC expression on mouse trophoblast affects uterine vascularization and fetal growth. Proc Natl Acad Sci USA. 108: 4012-4017.

MAO, G., WANG, J., KANG, Y., TAI, P., WEN, J., ZOU, Q., LI, G., OUYANG, H., XIA, G. and WANG, B. (2010). Progesterone increases systemic and local uterine proportions of $\mathrm{CD} 4+\mathrm{CD} 25+\mathrm{T}_{\text {Reg }}$ cells during midterm pregnancy in mice. Endocrinology 151: 5477-5488.

MARLIN, R., NUGEYRE, M.T., DURIEZ, M., CANNOU, C., LEBRETON, A., BERKANE, N., BARRE-SINOUSSI, F. and MENU, E. (2011). Decidual soluble factors participate in the control of HIV-1 infection at the maternofetal interface. Retrovirology 8: 58.

MJOSBERG, J., BERG, G., JENMALM, M.C. and ERNERUDH, J. (2010). FOXP3+ regulatory $T$ cells and $T$ helper $1, T$ helper 2 , and $T$ helper 17 cells in human early pregnancy decidua. Biol Reprod 82: 698-705.

MOLDENHAUER, L.M., DIENER, K.R., THRING, D.M., BROWN, M.P., HAYBALL, J.D. and ROBERTSON, S.A. (2009). Cross-presentation of male seminal fluid antigens elicits $\mathrm{T}$ cell activation to initiate the female immune response to pregnancy. J Immunol 182: 8080-8093.

MOLDENHAUER, L.M., HAYBALL, J.D. and ROBERTSON, S.A. (2010). Utilising T cell receptor transgenic mice to define mechanisms of maternal T cell tolerance in pregnancy. J Reprod Immunol 87: 1-13.

MUELLER, S.N., GEBHARDT, T., CARBONE, F.R. and HEATH, W.R. (2013). Memory T cell subsets, migration patterns, and tissue residence. Annu Rev Immunol 31: 137-161.

NAGAMATSU, T., BARRIER, B.F. and SCHUST, D.J. (2011). The regulation of Tcell cytokine production by ICOS-B7H2 interactions at the human fetomaternal interface. Immunol Cell Biol 89: 417-425.

NAGAMATSU, T. and SCHUST, D.J. (2010). The contribution of macrophages to normal and pathological pregnancies. Am J Reprod Immunol 63: 460-471.

NAKANISHI, Y., LU, B., GERARD, C. and IWASAKI, A. (2009). CD8(+) T lymphocyte mobilization to virus-infected tissue requires CD4(+) T-cell help. Nature 462 510-513

NAKASHIMA, A., ITO, M., SHIMA, T., BAC, N.D., HIDAKA, T. and SAITO, S. (2010), Accumulation of IL-17-positive cells in decidua of inevitable abortion cases. Am $J$ Reprod Immunol 64: 4-11.

NANCY, P., TAGLIANI, E., TAY, C.S., ASP, P., LEVY, D.E. and ERLEBACHER, A (2012). Chemokine gene silencing in decidual stromal cells limits $T$ cell access to the maternal-fetal interface. Science 336: 1317-1321.

PAESCHKE, S., CHEN, F., HORN, N., FOTOPOULOU, C., ZAMBON-BERTOJA, A. SOLLWEDEL, A., ZENCLUSSEN, M.L., CASALIS, P.A., DUDENHAUSEN, J.W., VOLK, H.D. et al., (2005). Pre-eclampsia is not associated with changes in the levels of regulatory T cells in peripheral blood. Am J Reprod Immuno/54: 384-389.

POOLE, D.H. and PATE, J.L. (2012). Luteal microenvironment directs resident T lymphocyte function in cows. Biol Reprod 86: 29.

PRINS, J.R., BOELENS, H.M., HEIMWEG, J., VAN DER HEIDE, S., DUBOIS, A.E., VAN OOSTERHOUT, A.J. and ERWICH, J.J. (2009). Preeclampsia is associated with lower percentages of regulatory $T$ cells in maternal blood. Hypertens Pregnancy 28: 300-311.

QUINN, K.H., LACOURSIERE, D.Y., CUI, L., BUI, J. and PARAST, M.M. (2011). The unique pathophysiology of early-onset severe preeclampsia: role of decidual $\mathrm{T}$ regulatory cells. J Reprod Immunol 91: 76-82.

REDLINE, R.W. (2007). Villitis of unknown etiology: noninfectious chronic villitis in the placenta. Hum Pathol 38: 1439-46.

ROBERTSON, S.A., PRINS, J.R., SHARKEY, D.J. and MOLDENHAUER, L.M. (2013) Seminal fluid and the generation of regulatory $T$ cells for embryo implantation. Am J Reprod Immunol 69: 315-30.

ROWE, J.H., ERTELT, J.M., XIN, L. and WAY, S.S. (2012). Pregnancy imprints regulatory memory that sustains anergy to fetal antigen. Nature 490: 102-106.

SAITO, S., NAKASHIMA, A., SHIMA, T. and ITO, M. (2010). Th1/Th2/Th17 and regulatory T-cell paradigm in pregnancy. Am J Reprod Immunol 63: 601-610.

SAITO, S., NISHIKAWA, K., MORII, T., NARITA, N., ENOMOTO, M., ITO, A. and ICHIJO, M. (1994). Astudy of CD45RO, CD45RAand CD29 antigen expression on human decidual T cells in an early stage of pregnancy. Immunol Lett 40: 193-197.

SAMSTEIN, R.M., JOSEFOWICZ, S.Z., ARVEY, A., TREUTING, P.M. and RUDENSKY, A.Y. (2012). Extrathymic generation of regulatory T cells in placental mammals mitigates maternal-fetal conflict. Cell 150: 29-38.

SANTNER-NANAN, B., PEEK, M.J., KHANAM, R., RICHARTS, L., ZHU, E., FAZEKAS DE ST GROTH, B. and NANAN, R. (2009). Systemic increase in the ratio between Foxp3+ and IL-17-producing CD4+ T cells in healthy pregnancy but not in preeclampsia. J Immunol 183: 7023-7030.

SASAKI, Y., DARMOCHWAL-KOLARZ, D., SUZUKI, D., SAKAI, M., ITO, M., SHIMA, T., SHIOZAKI, A., ROLINSKI, J. and SAITO, S. (2007). Proportion of peripheral blood and decidual CD4(+) CD25(bright) regulatory T cells in pre-eclampsia. Clin Exp Immunol 149: 139-145.

SASAKI, Y., SAKAI, M., MIYAZAKI, S., HIGUMA, S., SHIOZAKI, A. and SAITO, S. (2004). Decidual and peripheral blood CD4+CD25+ regulatory T cells in early pregnancy subjects and spontaneous abortion cases. Mol Hum Reprod 10:347-353.

SCHENKEL, J.M., FRASER, K.A., VEZYS, V. and MASOPUST, D. (2013). Sensing and alarm function of resident memory CD8(+) T cells. Nat Immunol 14: 509-513.

SCHUMACHER, A., BRACHWITZ, N., SOHR, S., ENGELAND, K., LANGWISCH, S., DOLAPTCHIEVA, M., ALEXANDER, T., TARAN, A., MALFERTHEINER, S.F., COSTA, S.D. et al., (2009). Human chorionic gonadotropin attracts regulatory $T$ cells into the fetal-maternal interface during early human pregnancy. $J$ Immunol 182: 5488-5497.

SHARKEY, D.J., MACPHERSON, A.M., TREMELLEN, K.P., MOTTERSHEAD, D.G., GILCHRIST, R.B. and ROBERTSON, S.A. (2012). TGF-beta mediates proinflammatory seminal fluid signaling in human cervical epithelial cells. $J \mathrm{Im}$ munol 189: 1024-1035.

SHIMA, T., SASAKI, Y., ITOH, M., NAKASHIMA, A., ISHII, N., SUGAMURA, K. and SAITO, S. (2010). Regulatory T cells are necessary for implantation and maintenance of early pregnancy but not late pregnancy in allogeneic mice. $J$ Reprod Immunol 85: 121-129.

SLUKVIN, II, MERKULOVA, A.A., VODYANIK, M.A. and CHERNYSHOV, V.P. (1996). Differential expression of CD45RA and CD45RO molecules on human decidual and peripheral blood lymphocytes at early stage of pregnancy. Am J Reprod Immunol 35: 16-22. 
SOMERSET, D.A., ZHENG, Y., KILBY, M.D., SANSOM, D.M. and DRAYSON, M.T. (2004). Normal human pregnancy is associated with an elevation in the immune suppressive CD25+ CD4+ regulatory T-cell subset. Immunology 112: 38-43.

STOUT, M.J., CONLON, B., LANDEAU, M., LEE, I., BOWER, C., ZHAO, Q., ROEHL, K.A., NELSON, D.M., MACONES, G.A. and MYSOREKAR, I.U. (2013). Identification of intracellular bacteria in the basal plate of the human placenta in term and preterm gestations. Am J Obstet Gynecol 208: 226 e1-7.

TAGLAUER, E.S., YANKEE, T.M. and PETROFF, M.G. (2009). Maternal PD-1 regulates accumulation of fetal antigen-specific CD8+ T cells in pregnancy. $J$ Reprod Immunol 80: 12-21.

TAGLIANI, E., SHI, C., NANCY, P., TAY, C.S., PAMER, E.G. and ERLEBACHER, A. (2011). Coordinate regulation of tissue macrophage and dendritic cell population dynamics by CSF-1. J Exp Med 208: 1901-1916.

TAMBLYN, J.A., LISSAUER, D.M., POWELL, R., COX, P. and KILBY, M.D. (2013). The immunological basis of villitis of unknown etiology - review. Placenta 34: 846-855.

TELES, A., SCHUMACHER, A., KUHNLE, M.C., LINZKE, N., THUERE, C., REICHARDT, P., TADOKORO, C.E., HAMMERLING, G.J. and ZENCLUSSEN, A.C. (2013a). Control of uterine microenvironment by foxp3(+) cells facilitates embryo implantation. Front Immunol 4: 158.

TELES, A., ZENCLUSSEN, A.C. and SCHUMACHER, A. (2013b). Regulatory T cells are baby's best friends. Am J Reprod Immunol 69: 331-339.

TILBURGS, T., CLAAS, F.H. and SCHERJON, S.A. (2010a). Elsevier Trophoblast Research Award Lecture: Unique properties of decidual T cells and their role in immune regulation during human pregnancy. Placenta 31 Suppl: S82-S86.

TILBURGS, T., ROELEN, D.L., VAN DER MAST, B.J., DE GROOT-SWINGS, G.M., KLEIJBURG, C., SCHERJON, S.A. and CLAAS, F.H. (2008). Evidence for a selective migration of fetus-specific CD4+CD25bright regulatory $T$ cells from the peripheral blood to the decidua in human pregnancy. $J$ Immunol 180: 5737-5745.

TILBURGS, T., ROELEN, D.L., VAN DER MAST, B.J., VAN SCHIP, J.J., KLEIJBURG, C., DE GROOT-SWINGS, G.M., KANHAI, H.H., CLAAS, F.H. and SCHERJON, S.A. (2006). Differential distribution of CD4(+)CD25(bright) and CD8(+)CD28(-) T-cells in decidua and maternal blood during human pregnancy. Placenta 27 Suppl A: S47-S53.

TILBURGS, T., SCHERJON, S.A., VAN DER MAST, B.J., HAASNOOT, G.W., VERSTEEG, V.D.V.-M.M., ROELEN, D.L., VAN ROOD, J.J. and CLAAS, F.H. (2009a). Fetal-maternal HLA-C mismatch is associated with decidual T cell activation and induction of functional T regulatory cells. J Reprod Immunol 82: 148-157.

TILBURGS, T., SCHONKEREN, D., EIKMANS, M., NAGTZAAM, N.M., DATEMA, G. SWINGS, G.M., PRINS, F., VAN LITH, J.M., VAN DER MAST, B.J., ROELEN, D.L. et al., (2010b). Human decidual tissue contains differentiated CD8+ effectormemory T cells with unique properties. J Immunol 185: 4470-4477.

TILBURGS, T. and STROMINGER, J.L. (2013). CD8+ effector T cells at the fetalmaternal interface, balancing fetal tolerance and antiviral immunity. Am J Reprod Immunol 69: 395-407.

TILBURGS, T., VANDERMAST, B.J., NAGTZAAM, N.M., ROELEN, D.L., SCHERJON, S.A. and CLAAS, F.H. (2009b). Expression of NK cell receptors on decidual T cells in human pregnancy. J Reprod Immunol 80: 22-32.

TOLDI, G., SAITO, S., SHIMA, T., HALMOS, A., VERESH, Z., VASARHELYI, B. RIGO, J., JR. and MOLVAREC, A. (2012). The frequency of peripheral blood CD4+ CD25high FoxP3+ and CD4+ CD25- FoxP3+ regulatory T cells in normal pregnancy and pre-eclampsia. Am J Reprod Immunol 68: 175-180.

TRUNDLEY, A. and MOFFETT, A. (2004). Human uterine leukocytes and pregnancy. Tissue Antigens 63: 1-12.

VASSILIADOU, N. and BULMER, J.N. (1996). Quantitative analysis of T lymphocyte subsets in pregnant and nonpregnant human endometrium. Biol Reprod 55: 1017-1022.

VERHAGEN, J. and WRAITH, D.C. (2010). Comment on "Expression of Helios, an Ikaros transcription factor family member, differentiates thymic-derived from peripherally induced Foxp3+T regulatory cells". J Immunol 185: 7129; author reply 7130.

WANG, W.J., HAO, C.F., YI, L., YIN, G.J., BAO, S.H., QIU, L.H. and LIN, Q.D. (2010). Increased prevalence of $T$ helper 17 (Th17) cells in peripheral blood and decidua in unexplained recurrent spontaneous abortion patients. J Reprod Immunol 84: 164-170.

WELSH, A.O. and ENDERS, A.C. (1985). Light and electron microscopic examination of the mature decidual cells of the rat with emphasis on the antimesometrial decidua and its degeneration. Am J Anat 172: 1-29.

ZHAO, J.X., ZENG, Y.Y. and LIU, Y. (2007). Fetal alloantigen is responsible for the expansion of the CD4(+)CD25(+) regulatory $\mathrm{T}$ cell pool during pregnancy. $J$ Reprod Immunol 75: 71-81.

ZHU, J., YAMANE, H. and PAUL, W.E. (2010). Differentiation of effector CD4 T cell populations. Annu Rev Immunol 28: 445-489. 


\section{Further Related Reading, published previously in the Int. J. Dev. Biol.}

Immunoregulatory molecules in human placentas: potential for diverse roles in pregnancy

Joan S. Hunt, Judith L. Pace and Ryan M. Gill

Int. J. Dev. Biol. (2010) 54: 457-467

http://www.intjdevbiol.com/web/paper/082831jh

The hidden maternal-fetal interface: events involving the lymphoid organs in maternal-fetal tolerance Elizabeth S. Taglauer, Kristina M. Adams Waldorf and Margaret G. Petroff Int. J. Dev. Biol. (2010) 54: 421-430

http://www.intjdevbiol.com/web/paper/082800et

On the role of placental major histocompatibility complex and decidual leukocytes in implantation and pregnancy success using non-human primate models

Thaddeus G. Golos, Gennadiy I. Bondarenko, Svetlana V. Dambaeva, Edith E. Breburda, and Maureen Durning

Int. J. Dev. Biol. (2010) 54: 431-443

http://www.intjdevbiol.com/web/paper/082797tg

Split immunological tolerance to trophoblast

Amanda de Mestre, Leela Noronha, Bettina Wagner and Douglas F. Antczak

Int. J. Dev. Biol. (2010) 54: 445-455

http://www.intjdevbiol.com/web/paper/082795ad

Immune cells in the placental bed

Judith N. Bulmer, Paula J. Williams and Gendie E. Lash

Int. J. Dev. Biol. (2010) 54: 281-294

http://www.intjdevbiol.com/web/paper/082763jb

5 yr ISI Impact Factor $(2011)=2.959$
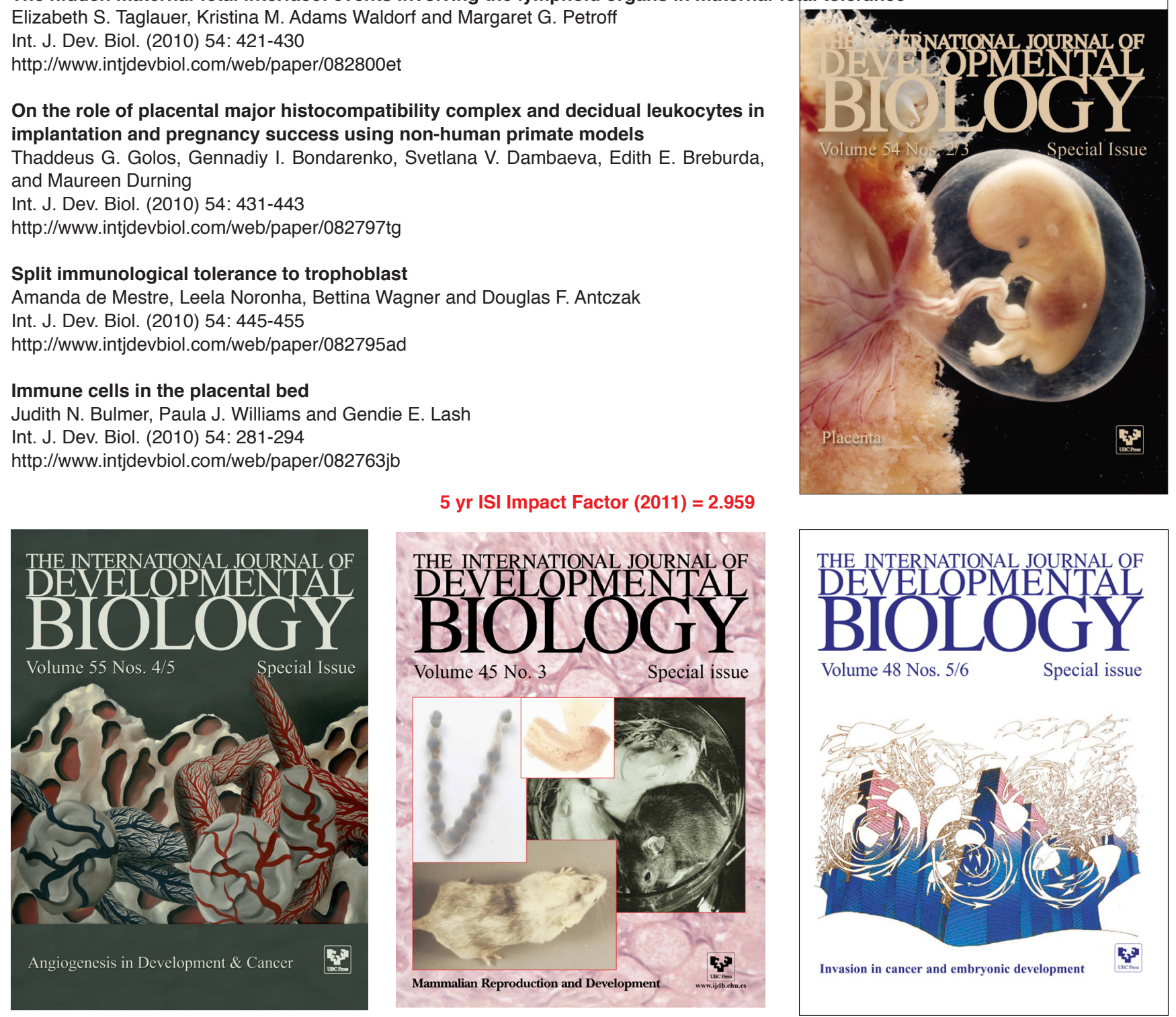

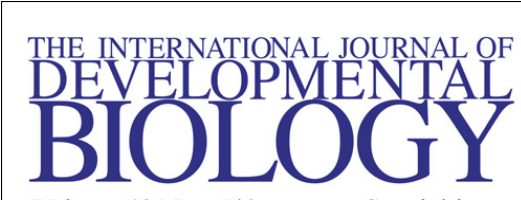

Volume 48 Nos. $5 / 6$

Special issue

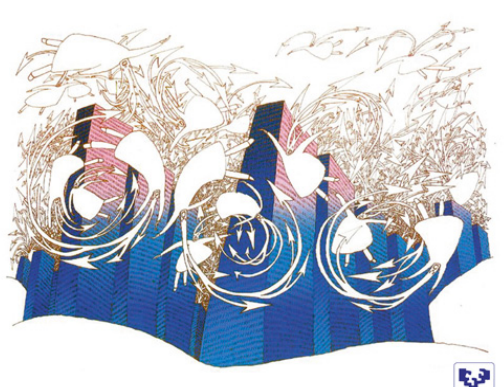

Invasion in cancer and embryonic development 